\author{
As Barack Obama sets a fresh agenda for the US approach to climate change and energy, scientists \\ must make sure that they do not merely watch from the sidelines.
}

or months now, US president-elect Barack Obama, his economic advisers and the incoming Congress have been in broad agreement. They believe that the worst recession in decades should be fought not just through short-term job creation, but by pouring hundreds of billions of dollars into long-term investments - including huge pushes in education, science and technology (see page 240).

That prospect has US scientists almost rubbing their hands in anticipation. But they would be wrong to view this simply as a chance to get more money. They will also need to help Obama clean up George W. Bush's legacy on science-related issues ranging from nuclear non-proliferation (see page 250) to endangered species (see page 252). And they must help him retool the scientific capabilities of agencies throughout the federal government. Some early road maps towards that goal can be found on page 258, where experts discuss issues from fixing the Food and Drug Administration to revitalizing the country's embryonic stem-cell research programme.

There is one area that definitely needs a well-organized and massive injection of funds: climate change. The United States now has an opportunity to wean itself off fossil fuels and move towards carbon-free sources of energy. But the government must commit itself to a rational, well-organized plan for doing so, and then sustain that plan into the future.

It is promising that Obama has already put an emphasis on energy efficiency. This is a priority of energy-secretary nominee Steven Chu (see page 241) and is the approach that offers by far the biggest energy saving per dollar invested. A less promising idea is the Advanced Research Projects Agency for Energy, or ARPA-E, which is meant to be modelled on the defence-research agency DARPA. Chu has supported this, congressional leaders are behind it, and on the surface it sounds like a good idea: putting bright minds in a single leanand-mean agency to come up with radical energy innovations. But,

as this journal has noted before, ARPA-E must be structured very carefully to escape gridlock from the competing industry interests that otherwise drag down federal efforts at energy reform (see Nature 438, 129; 2005).

The biggest question, however, is how the United States will contain its greenhouse-gas emissions. A tax on carbon would be the most straightforward route, but is not politically feasible. Obama has advocated a cap-and-trade system for regulating emissions, a system that - at America's early insistence - has become the model of choice internationally. The United States must now learn the right

"One area that definitely needs a well-organized and massive injection of funds is climate change." lessons from the European emissions-trading system - don't give away allowances for free, for example, or sell them too cheaply — in order to institute its own system effectively.

Obama must also set up the infrastructure to support such a system and to drive a low-carbon economy. One top priority is expanding and improving the electricity grid to accommodate solar and wind energy. Another is a long-term adaptation strategy to help the nation's cities and states cope with the changing climate. But solving these and other such problems will require new policies and decades of reliable investment.

By putting these issues on the table before being sworn into office on 20 January, Obama has established climate as a major priority for his administration. Now he needs to follow through. Around Washington the talk is that climate is like health care in 1993, when incoming president Bill Clinton made it a signature issue and put his smartest people on it - only to watch it fail spectacularly. Scientists must help Obama ensure that climate action doesn't suffer the same fate.

\section{The biggest threat?}

\section{The Obama administration must help prevent terrorists from building a nuclear device.}

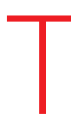
he US president should have someone reporting directly to him, who has no other mission other than "to wake up every morning thinking: 'What can I do today to keep nuclear weapons out of the hands of terrorists?"' That 2002 recommendation comes from a report co-authored by John Holdren, who is now scientific adviser to US president-elect Barack Obama. It is good news that Holdren understands the key nuclear non-proliferation issues, as bold US leadership is urgently needed to renew such efforts, especially given the damage done to these initiatives under the administration of George W. Bush (see page 250).

Holdren also understands that getting the international cooperation, and impetus, needed to revitalize non-proliferation will demand that the United States and other nuclear-weapons states make greater efforts to reduce their own arsenals and stockpiles. Obama could relay a strong message here by sending the Comprehensive Test Ban Treaty to the Senate for ratification.

Tangible steps could also be taken at once to substantially reduce the immediate threat of nuclear terrorism. What has been lacking is political will: a trade deal on bananas gets greater political priority than does non-proliferation. National and international measures to counter nuclear terrorism remain scandalously spartan and fragmented, and not remotely commensurate with the scale of the threat.

US support for all non-proliferation has been flat at between $\$ 1$ billion and $\$ 1.5$ billion annually over the past decade, or around $0.2 \%$ of 